INDEPENDENT JOURNAL OF MANAGEMENT \& PRODUCTION (IJM\&P)

http://www.ijmp.jor.br

v. 10, n. 4, Special Edition IFLOG 2018

ISSN: 2236-269X

DOI: 10.14807/ijmp.v10i4.956

\title{
ANALYSIS AND EVALUATION OF THE RISKS OF BIRD STRIKES IN THE INTERNATIONAL GUARULHOS AIRPORT SURROUNDINGS
}

\author{
José Carlos Ribeiro \\ FATEC Professor Jessen Vidal College, Brazil \\ E-mail: jotakaribe51@gmail.com
}

Devanildo Damião

Sao Paulo University, Brazil

E-mail: devanildo@gmail.com

Submission: 01/3/2019

Accept: 02/8/2019

\section{ABSTRACT}

The first catastrophic avian impact victim killed Cal Rogers in 1912 in the United States. The most recent and catastrophic accident by bird striking occurred on August 11, 2016 with Airbus A320 aircraft apparently after striking at least one bird upon takeoff from New York's LaGuardia Airport. The aircraft landed safely on Hudson River. Fortunately everybody still alive, even though the loss of aircraft hull. The purpose of this study is to present the panorama of the bird strikes, to identify, evaluate the propensities and to present the propositions to mitigating the bird strike risks in the surroundings of the Guarulhos International Airport (SBGR). This study is based on probabilistic and heuristic methods to infer about the risk propensities of avian strikes. The study of bird strikes and risk management are essential to anticipate and minimize the severity and reduction of frequency of occurrences. The results of the statistical analyze point to the flight densities and the frequency of events due to the migratory periods of the neotropic and endemic birds. Native populations of birds travel between the Serra do Mar, the Mata Atlântica and forests around the airport to the Serra da Cantareira forest. Impact events are strongly correlated with the density of aircraft movements in the SBGR.

Keywords: strike; birds; risks; airfreight; Guarulhos 
INDEPENDENT JOURNAL OF MANAGEMENT \& PRODUCTION (IJM\&P)

http://www.ijmp.jor.br

v. 6, n. 2, April - June 2015

ISSN: 2236-269X

DOI: 10.14807/ijmp.v6i2.278

\section{INTRODUCTION}

Presents the summary the set of statistical values for the tabulation of descriptive statistical data and presents the data of the population of the most significant and critical specimens in the scope of this study discretized in the sample form. The topics of relevance to the study are taken into account.

The nesting of the Southern Lapwing (Vanellus chilensis) as well as bureaucratic owls occurs in low-grazing areas, especially in airport environments. Vultures and hawks nest in tops of trees and hollowed trunks amid the woods. These factors potentially increase the probabilities of impact with aircraft and various obstacles in the ground.

The main natural inhibitors in the activities and nesting of the largest portion of the faunal population are strong winds. The nesting period occurs from beginning of spring to summer, characterized by the great activity of the avifauna. Birds of North America migrate to the South during this period. Reciprocally, birds from the South migrate to the tropical and equatorial areas.

According to the IMCBio (2015), the most obvious Brazilian routes are the coast, from Amapá to Rio Grande do Sul States (Atlantic Route) and the Atlantic Route branch, from the mouth of the Amazon River, mouths of the Tocantins and Xingu Rivers. These routes cross from the Central Plateau to the Paraná and São Paulo Rivers Valley Figure 1. Other routes reach the South American Continent. According to CONAMA report No. 462 (2014).

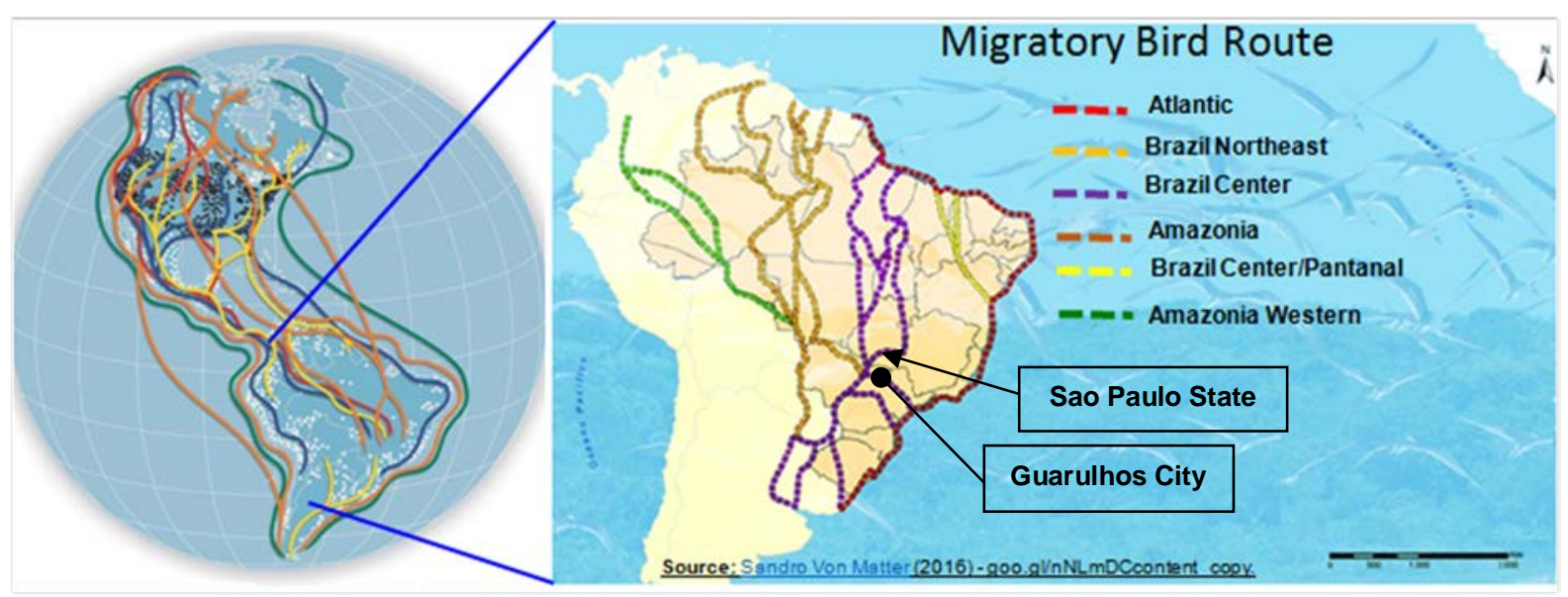

Figure 1: Routes of the North and South America

Source: ICMBio (2016), modified by Author. 
INDEPENDENT JOURNAL OF MANAGEMENT \& PRODUCTION (IJM\&P)

http://www.ijmp.jor.br

v. 10, n. 4, Special Edition IFLOG 2018

ISSN: 2236-269X

DOI: 10.14807/ijmp.v10i4.956

ICMBio (2014) states that "at least 197 species have some migration pattern considered as migratory." According to Souto (2015) shorebirds enter Brazilian territory from September to March through the Amapá, Pará and Maranhão States, after moving another 30,000 km towards Rio Grande do Sul State for summer the reciprocal migratory bird routes at North and South America passing by Brazil.

From that total (197), 53\% (104 species) reproduce in Brazil and another 47\% (93 species) in other countries. These species have elongated legs and long beaks adapted to feed on animals in the sand and water, such as Herons, Coastal Gulls, Mallard, Flamingos, Batuiras, Torches and others. São Paulo State was covered by $80 \%$ by Atlantic Forest and a fraction of Cerrado Forest.

Ferreira, et al. (2011) relate that Guarulhos City has $320 \mathrm{~km} 2$ of territorial area and only $33 \%$ of forest remains. Today around 3\% cover Guarulhos City the vegetal remains as the Maia Forest which is mentioned, and on the Southeast side of SBGR the Forest of São Paulo Air Base (BASP). Others dispersed environmental conservation areas exist Figure 2.

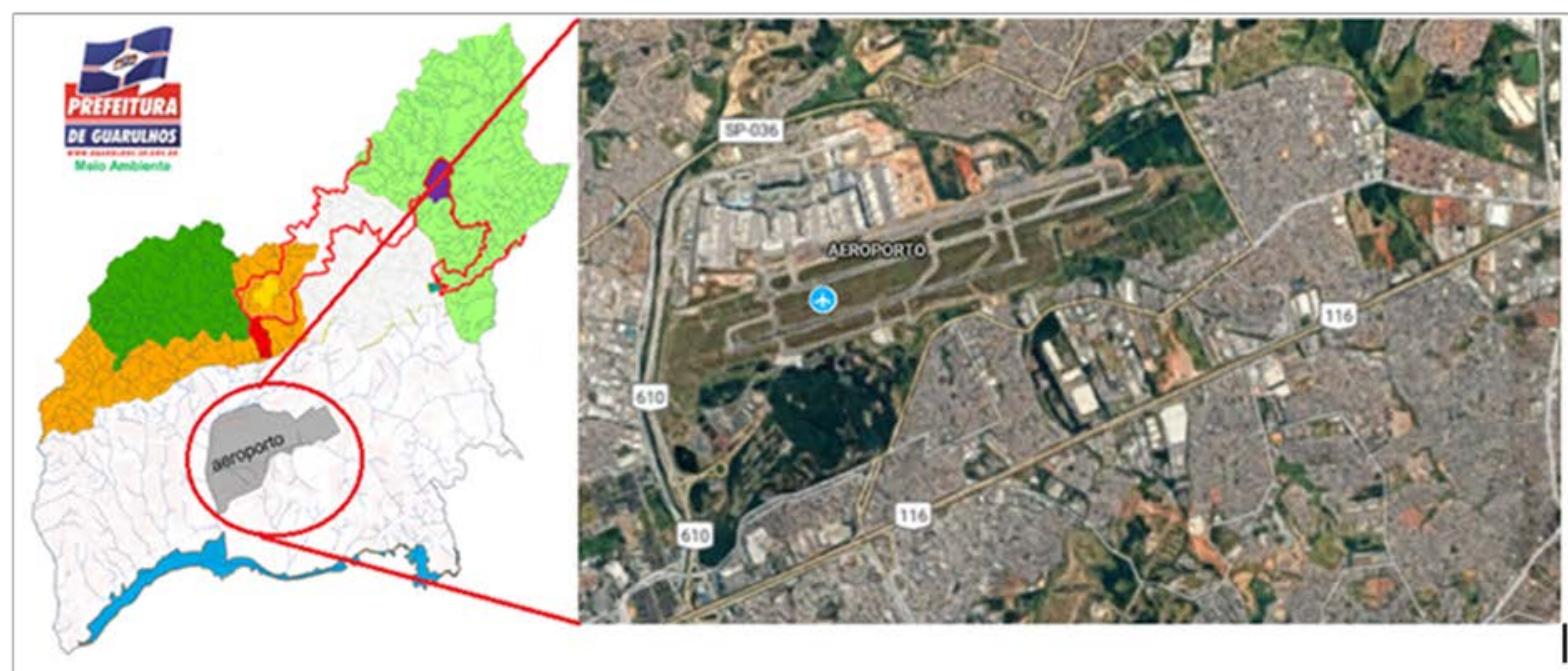

Burle Marx Biological Reserve

Dindinha NaturalEnvironmental Preservation Area Tanque Grande Ecological Station

Cabuçú-Tanque Grande Environmental Preservation Area

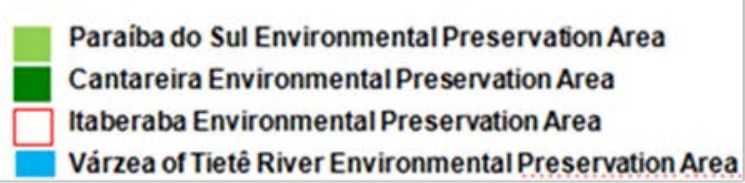

Figure 2: Conservation Units and forests of Guarulhos Airport.

Source: City Hall of Guarulhos/Google Maps (2017), modified and adapted by author.

This is a result of the negative direct and indirect impacts of anthropogenic actions, the imbalance of the ecosystem and traditional biodiversity forces birds to move from their natural habitats to the vegetation in the Cantareira Hill and Mar Hill 
regions as shown at Guarulhos International Airport map and vegetation surroundings. Others specimens exist in the Green Belt Biosphere Reserve of the City of São Paulo (RBCV), such as the State Park of Ipiranga Headwater, Carmo Park, Ibirapuera Park. Also worth mentioning the Tietê Ecological Park, located in the environmental preservation zone between the two arms of the Ayrton Senna Highway (SP-070) and the banks of the Tietê River.

Although in a very insipient way, advances have been achieved in the transitions from the reactive postures, to the preventive ones and lately the proactivity to a fragmented system in attention to the fauna questions. The protectionism of mercantilist interests still surpasses regions, forests and ecosystems; challenge statistics, confront danger with safety, denote palliative actions to the essentials of air travel and the value of life.

Constitution of the Federative Republic of Brazil, promulgated on October 5, 1988, in Chapter VI - Environment, Article 225: "Everyone has the right to an ecologically balanced environment, as well as common use of the people and essential to the healthy quality of life, imposing on the Public Power and the collective the duty to defend and preserve it for present and future generations" (BRAZIL. 1996: 131). This Constitution explicitly also in Article 225 of the Constitution of the Federative Republic of Brazil, paragraph 1, item V: "Control the production, marketing and use of techniques, methods and substances that present a risk to life, quality of life and environment; $\ldots "$

By the inventory of the Guarulhos Municipal Zoo concluded 2010 there were 501 specimens at Guarulhos City fauna like as the Great Kiskadee (Pitangus sulphuratus - Bem-te-vis), the Cormorants (Biguás), the Brazilian Squirrel (Sciurus Aestuans - Caxinguelês), the Seedeater (Charadrius collaris - Coleirinhas), the Owleared, the Great White Egrets (Ardea alba), the Little White Egrets, the Monkey-pickers Hawks, the Dusky-legged Guan (Jacuguaçus), the Southern Lapwing (Vanellus chilensis - Quero-queros), the Ruffous-bellied-thrush (Turdus rufiventris - Sabiáslaranjeira), the Gray Hawks (Gaviões-Carijós), Toucans and others. In terms of biodynamics, Carvalho (1995) also cites piscivorous birds such as the White Storks, the Cow Herons, the Martim-angler, Brazilian Merganser (Mergus octosetaceus); the molluscivore bird like as the Snail Kite (Rostrhamus sociabilis - Caramujeiro). Others 
DOI: 10.14807/ijmp.v10i4.956

specimens such as the Harpy Eagle (Gavião-carrapateiro), search for food in clandestine garbage dumps and irregular dumps, sanitary landfills, which create attractions for certain types of omnivorous and omnivorous birds, such as the Caracarás (Caracara caracara), or the Southern, or Common Caracara and the Black Vultures (Coragyps atratus). However identification and quantification of bird population and bird species variations and their behavioral characteristics are restrictive factors to guide effective and protective measures, since overpopulations interfere with air traffic.

ACRP Report 125 (2015) recommends developing airport management models to mitigate the risks of avian impacts, reduce their probabilities and severities, and improve organizational cultures in air operations in relation to wildlife events. The initial milestone of aviation is also characterized by the historical threshold of collisions of aircraft with birds. The impact of the aviary impinges heavily on global aviation, severe structural damage to aircraft and even catastrophic loss of lives and losses of billions of dollars annually in world civil aviation.

Oliveira et al. (2015) emphasize that the indirect costs per bird collision, for example, are estimated between US\$28,000 and US\$30,000 for canceled national flight and US\$200,000 for international flights. "These are the known values, but if we take into account that the operators do not always adequately inform the costs, we can say that the impact of the collisions for Brazilian aviation is much higher" said them. Brazilian aviation estimates spending above US\$13,000 with repair of structural damages due to avian impact.

While in the US an estimated US $\$ 600$ million per year. Most collisions with birds of various species and provenances occur near the airports at low altitude during the approach, landing, takeoff and climb phases. In detriment to the peculiar characteristics of the Guarulhos biogenesis and the migratory dynamics, they make the aircraft susceptible to the events of avian impact.

The development of new risk mitigation methods and systems within an acceptable level is in line with the Bird Strike Control program of the International Civil Aviation Organization (ICAO). ACRP Report 125 (2015) relates that "Airports are unique and differ in terms of location, local environmental regulations, fauna, users, and / or resources." This study converges to São Paulo TMA (Terminal Control Area), 
INDEPENDENT JOURNAL OF MANAGEMENT \& PRODUCTION (IJM\&P)

http://www.ijmp.jor.br

v. 10, n. 4, Special Edition IFLOG 2018

ISSN: 2236-269X

DOI: 10.14807/ijmp.v10i4.956

CTR (Control Zone), APP (Approach Control) and ATZ (Air Traffic Zone) of SBGR. The reason for choosing the SBGR as the focus of the studies is due to the high annual movement and to constitute a corridor and port of entry and exit of the air traffic in SBGR.

According to the CGNA (2016) the SBGR accounts for $94 \%$ of the movements in commercial aviation, of these $71.7 \%$ originated and destined to the national territory. The Northeast and South regions were the highlights in participation in the flow of movements with $32.3 \%$ and $26.0 \%$, respectively. SBGR participated with $27.1 \%$ in international connections.

\section{LITERATURE REVIEW}

For Dolbeer (2006) apud Oliveira (2015) "74\% of reported collisions, $66 \%$ of them with substantial damage, occur below 500 feet above ground level." It also emphasizes that collisions occur with black-headed vultures and common frigates above those altitudes, importance should be given to the probabilities of occurrences around the airport site.

Flight altitudes during migrations vary depending on species and weather conditions, from below 600 meters up to 6,000 meters. Accord with SICK (1985) "Radar records on the coast of England revealed that passerines migrate below 1,500 meters and at night rise to some 4,000 meters. Pough et al. (1993) agree "There is still a record of species that reach altitudes above 6,500 meters.

According to Dolbeer (2006) apud Vaira (2012), in his analytical results and based on the regression equations, he concluded that $24 \%$ of the avian impacts (dependent variable) occur above 152 meters (500 feet) AGL (Above Ground Level). When in the search for food or in return for rest the height is below 150 meters. The data resulting from correlations between avian impacts and height, using the negative exponential height model as independent variable, with 99\% confidence and with standard deviation of the dependent variable of R2 $=0.9891$, according to Equation 1 .

$E_{\text {strike }}=4.469 e^{-(0,3846 * \text { feet above ground level })}$

The graph in Figure 3 shows the probability of the risks concerning to bird strikes a function of height. 


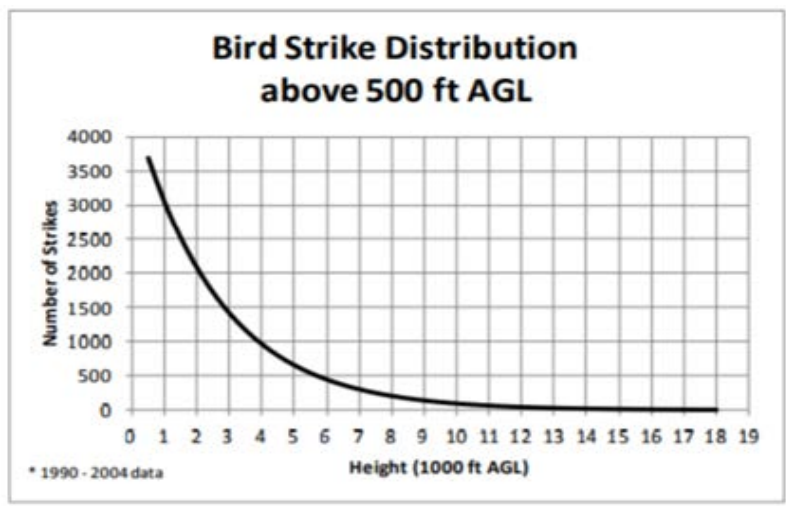

Figure 3: Number of bird impacts as a function of height Source: Vaira (2012, p 11)

For the Society for Risk Analysis apud Sánchez (2011) the risk "... is the potential for unwanted results to occur for human health or life, for the environment or for material goods". The risk, otherwise, is the product of the magnitude of the consequence resulting from a probable event occurring. However this study is summarized in the analysis of the probabilities of occurrence of the events of bird impacts.

Sánchez (2011) also defines the danger "... as a situation or condition that has the potential to have undesirable consequences." In the context of aviation safety, ICAO (2013) defines as "The state in which the possibility of injuring people or causing damage to property is reduced, stabilized or below an acceptable level by means of a process continuous risk identification and risk management."

In addition Ashford (2015) defines that "Security assurance is the set of interrelated activities which ensures that the operational controls designed to mitigate risks are working properly."

The probabilistic study is based on the difficulties imposed by organizational cultures, which do not always report in a systemic way the events of sightings and collisions. These endemic and segmented factors make complex access to concise and identifiable data. Of the total of bird involved only $57 \%$ were identified.

Accord with Novaes and Cintra (2015) apud Oliveira et al. (2015) "The factor that most limits the efficient management of fauna risk is the imprecision in the identification of species involved in each event. This condition is fundamental for the establishment of control measures, even among Brazilian aviation problem species, which are often considered the same, such as the black-headed vulture and the red- 
INDEPENDENT JOURNAL OF MANAGEMENT \& PRODUCTION (IJM\&P)

http://www.ijmp.jor.br

v. 10, n. 4, Special Edition IFLOG 2018

ISSN: 2236-269X

DOI: 10.14807/ijmp.v10i4.956

headed vulture". Defines risk as "The expected probability and severity of consequences or arising from a hazard".

ACRP 125 (2015) concerning the Risk Management System (SMS) defines "The risk assessment tool as a product of severity and probability". The risk of a bird impact is allowed to increase if the severity (extent of damage to the aircraft) or with the increased likelihood of occurrence.

Severity of impact is affected by size or number of birds bumped. Sánchez (2011) says the consequences come from the associated risks, as soon as "If risk is understood as the combination of the probability of a failure occurring with the magnitude of the consequences. Then risk management must act on both and accident prevention measures should be associated with considerations of location of the enterprise".

For ICAO (2013) the security management is "A systematic approach to managing flight safety, including organizational structures, accounting, policies and procedures required." With regard to safety ICAO (2013) also adds that "Within the context of aviation, safety is the state in which the possibility of harming people or causing property damage is reduced to and maintained below, at an acceptable level through a continuous process of identification and management of flight safety risk".

\section{METHODS}

The specific objective of this study is to describe the avifauna system in the context of the impact events with aircraft in the SBGR, to identify the hazards, to analyze, to evaluate the risks and to emphasize the mitigating actions. Inferring on the social, economic and environmental consequences of new risk trends based on ex post events in the SBGR CTR area.

From the perspective of risks, severity and probability of occurrence, the secondary objective is to understand, analyze and evaluate the probable causes of aeronautical incidents and accidents due to avian impact, in order to argue about the probability of occurrence.

The analysis of avian presence and susceptibilities of commercial aircraft point to the avian impacts in the area of the highest air traffic density in Sao Paulo State. This airspace is controlled and protected by the SBGR ATZ during descent, 
approaching and landing phases (CTR or APP) and intermediate stage after takeoff and climbing phases.

Understanding and figure out the chains of events are mixed in proposing solutions to airport operators and airlines. Ponder by simple methods on the attributes of the causes and probabilistic effects and related to the events of aviary collisions and relevant to flight safety. This overview promotes and emphasizes alternative statistical proposals for future contributions in the mitigation of bird impact events in Brazilian commercial aviation.

It is worth, then, of some techniques and statistical tools to understand the data and information, in order to formalize the descriptions, analyzing and understanding, in order to formulate and infer statistically about the results of this study. Then this study is based on probabilistic and heuristic methods to estimate the probability of avian impacts in the SBGR perimeter area.

Peak hour variations, daily and monthly movements will be considered, relating them to the behaviors of the endemic avifauna in the surroundings of the SBGR. Correlations will be made with the statistical data of the events of avian impact from years 2008 until 2016. It is divided into descriptive statistics and probability functions, in order to infer about the uncertainties arising from the phenomena characterized by discrete randomness.

The population of the avian specimens involved is quite diverse. Searches are conducted based on stratified sampling, selecting the most recurrent, most significant of the severity of the effects of impacts and whose frequencies are higher. The typologies of the main birds involved, regionalized and in transition in the SBGR vicinal areas were selected and considered in these studies.

Also take into account the flight training patterns, habits, nesting, seasonality, habitats, routes and migratory period and dynamic behavior. Correlations are done between peak hours of airport movement and the behavioral dynamics of the birdlife. Surveys were based on historical analyzes and systematic tabulation of statistical data on accidents and incidents. Relevant literature was searched, such as national and international articles, specialized books and specific government publications.

\section{RESULTS}


INDEPENDENT JOURNAL OF MANAGEMENT \& PRODUCTION (IJM\&P)

http://www.ijmp.jor.br

v. 10, n. 4, Special Edition IFLOG 2018

ISSN: 2236-269X

DOI: 10.14807/ijmp.v10i4.956

The migratory routes of the Americas make Brazil attractive to birds. The Northeastern region of Sao Paulo States concentrates one of the most important areas for migratory avifauna and air traffic. The highest collision rates occur during the approach, landing, and take-off phases of aircraft. For Ashford (2013) "Currently the damage tends to be minority, such as cracks in windshields, wing flap dents and minor fuselage damage". Figure 4 presents the movements of aircraft and bird strikes reported in SBGR from 2009 to 2016 and correlates to number of Brazil commercial aircrafts.

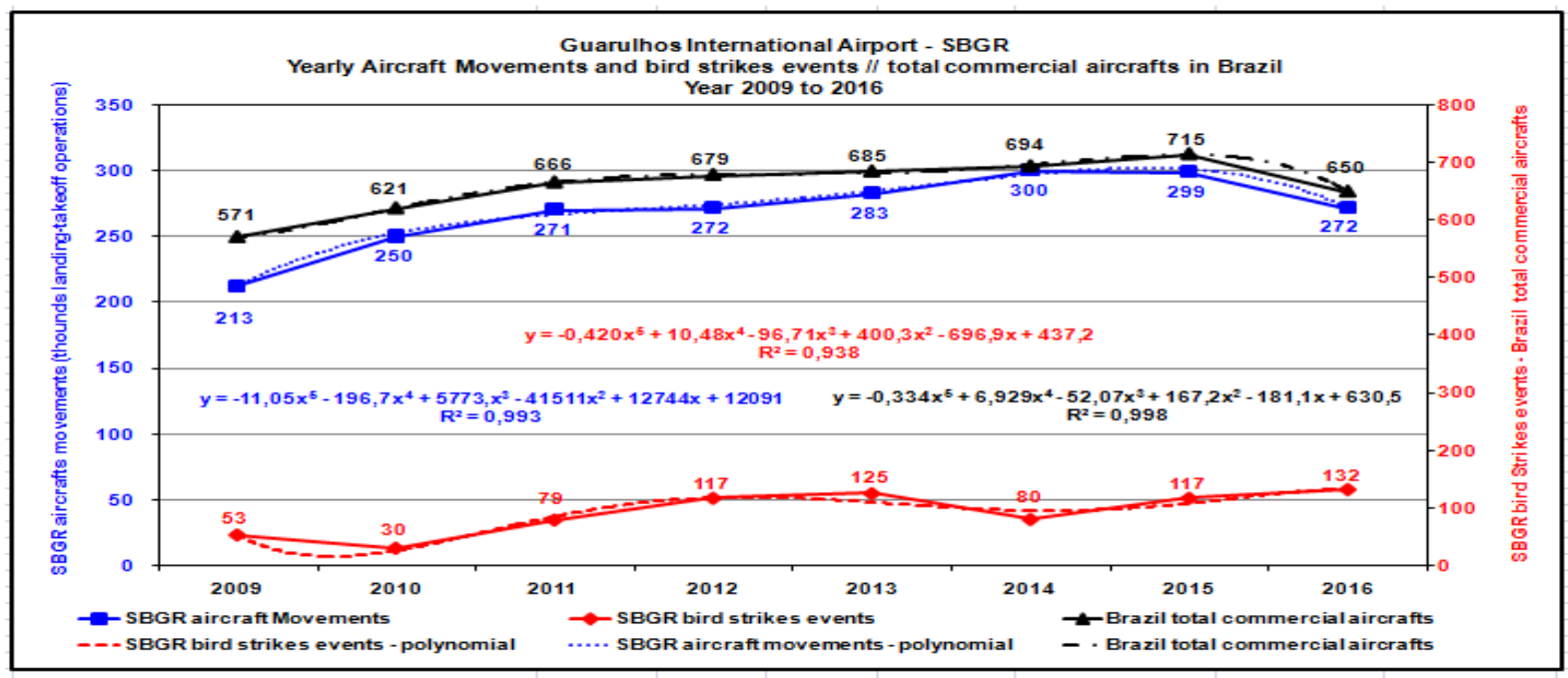

Figure 4: Aircrafts movements and bird strikes events Source: The Author. (2017).

The total number of collisions in the Brazilian public transport aviation has grown quietly due to the increase in movements and the number of aircraft. For Grimaldi (2011) "The probability of an accident is greater in the airport area during the take-off and landing phases and especially at dawn and in the afternoon." Grimaldi complements that lately the severity and importance of the events of aviary impacts increase proportional direct with increase of the air traffic, is also due to the modern aircraft to develop greater speeds.

This agreement to Ashford (2015) "Where there is a large amount of seasonal traffic, usually related to the holiday season, there may be substantial differences in scheduling policies between winter and summer operations." Fonseca and Martins (1994) in yours researches there are limitations to the finite sampling space of the most significant and frequent species of faunal species in avian collisions. Although the sample space is mutually exclusive, the opposite may occur in cases of impacts with Hawks and the Southern during persecutions to other species. 
INDEPENDENT JOURNAL OF MANAGEMENT \& PRODUCTION (IJM\&P)

http://www.ijmp.jor.br

v. 10, n. 4, Special Edition IFLOG 2018

ISSN: 2236-269X

DOI: 10.14807/ijmp.v10i4.956

Therefore, the unidentified species are partitioned into the probable sample space and related to the main specimens like as Southern Lapwing, Buzzards, Caracaras, Owls and Hawks, as shown at Figure 5 for the number of collisions from years 2009 until 2015.

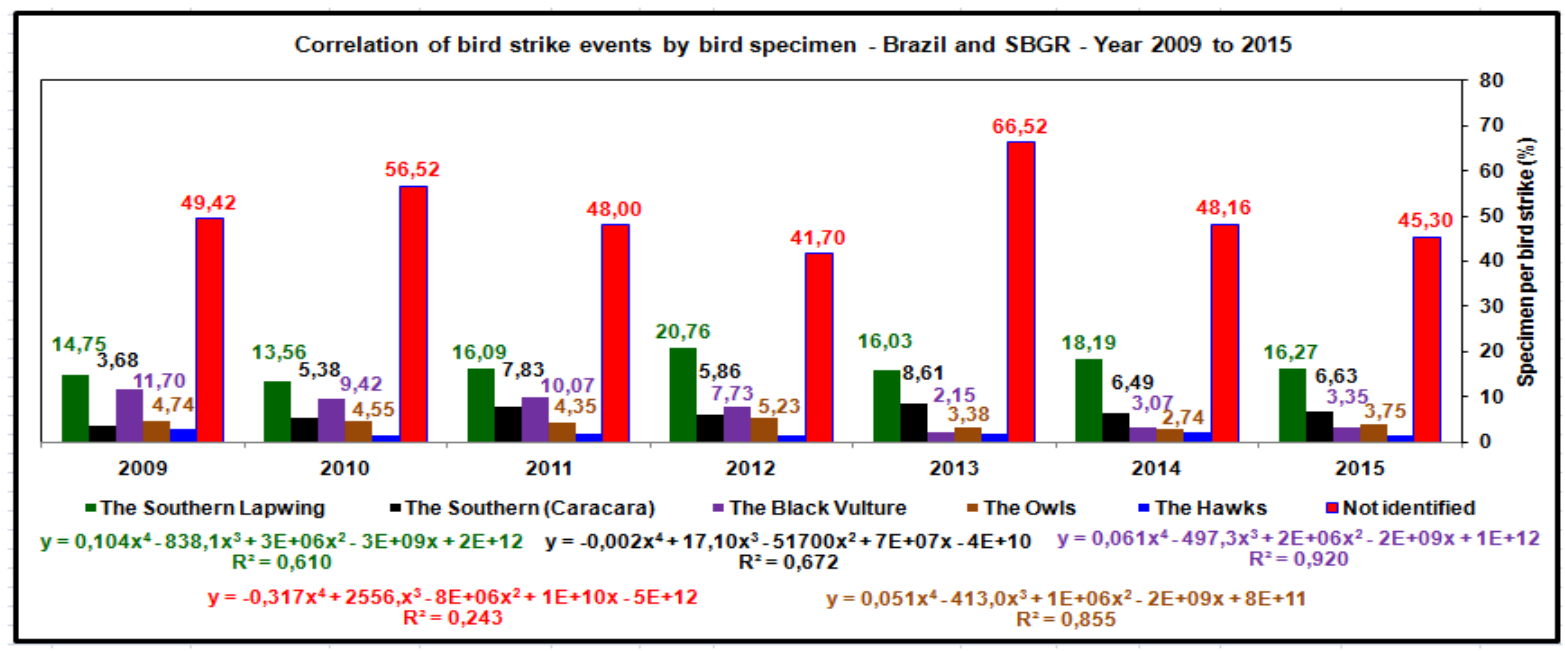

Figure 5: Number of annual collisions in Brazil and specimens Source: The Author (2017).

The bird strikes are directly proportional to the numbers of landing, takeoff, and peak hour. It is accentuated in the migratory periods and climatic seasonality, too. In the months of September there is a new establishment of the growth of occurrences, culminated and proportional to the number of aircraft movements in the SBGR. The bird strikes increase from January due to the greater movement of the aircraft and decay in July due to the migratory period Figure 6.

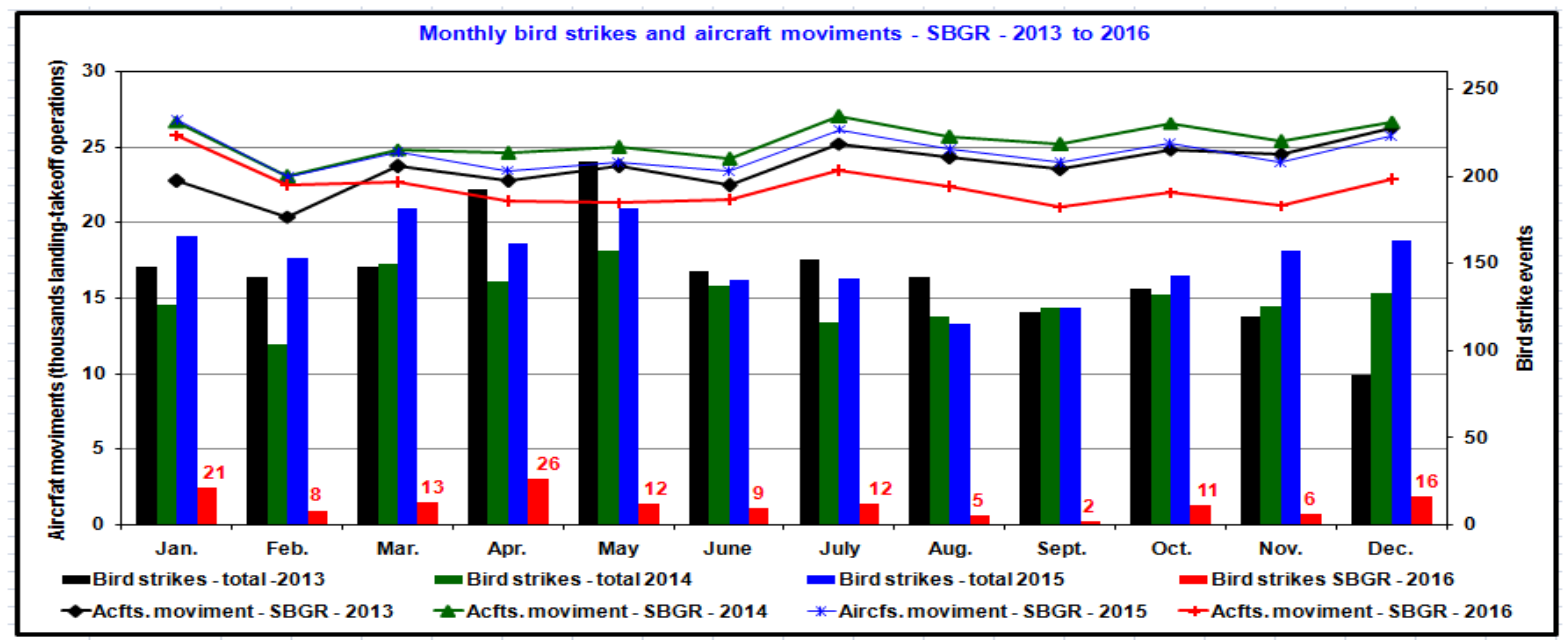

Figure 6: Average of the movements and their peak times Source: The Author. (2017). 
INDEPENDENT JOURNAL OF MANAGEMENT \& PRODUCTION (IJM\&P)

http://www.ijmp.jor.br

v. 10, n. 4, Special Edition IFLOG 2018

ISSN: 2236-269X

DOI: 10.14807/ijmp.v10i4.956

The smallest striking rate occurs from January to February. However the frequency of collisions increases from September with a new migratory cycle and accentuated by the summer solstice. According to ICAO (2017) 3\% avian impacts occur at dawn, 68\% during the day, 4\% at dusk and 25\% at night Figure 7.

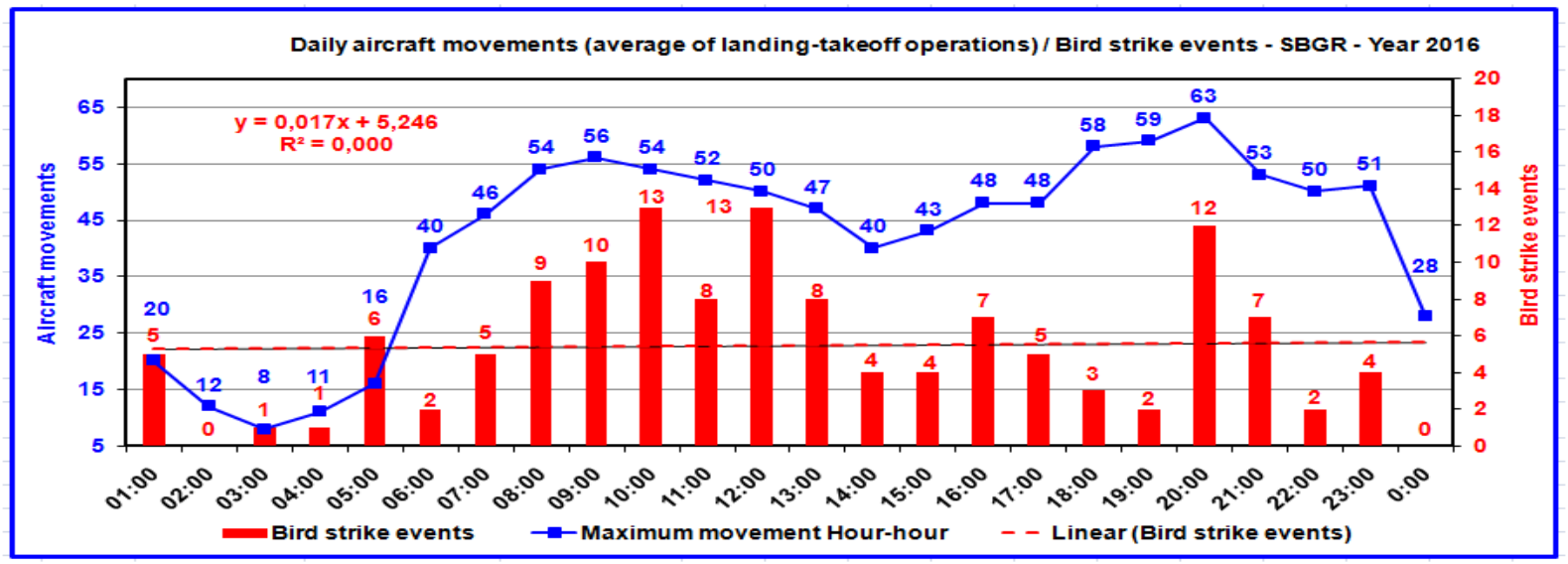

Figure 7: Bird strike events by daily average movements Source: The Author. (2018).

The periods of hyperactivity are dedicated to eating, thereby decreasing throughout the day and increasing at dusk. The nocturnal birds (Owls) begin their activities after dusk until 21 hours.

According to Quinalha et al. (2011), bird activities are more prominent between 6 a.m. and 10 a.m. in the morning and between 3 p.m. and 6 p.m., depending on each species, which coincides with the peak ranges of the periods of greatest incidence of impacts occur from May to October. Between 10 p.m. and 4 a.m., impacts with owls culminate with the movement of cargo aircraft, whose operating frequencies are more prominent.

Anderson et al. (2011) agree with research results of Neubauer, Fleet and Ayeres (2015), because "With the growth of air traffic, the number of accidents tends to increase if the level of safety remains constant". However fatalities, even small ones, are still evident in world aviation statistics.

ICAO (2013) clarifies that "As long as the elimination of serious aircraft accidents and/or incidents remains the ultimate goal, it is recognized that the aviation system cannot be completely free of the associated hazards and risks." Accord with Silva (2015) "Among the species that most collide are the Southern Lapwing, the Black-headed Vulture and the Caracaras." 
INDEPENDENT JOURNAL OF MANAGEMENT \& PRODUCTION (IJM\&P)

ICAO (2013) clarifies that "As long as the elimination of serious aircraft accidents and/or incidents remains the ultimate goal, it is recognized that the aviation system cannot be completely free of the associated hazards and risks." According to Ashford (2013), even if catastrophic events with life losses are possible, the potential risks are latent in the vicinity of the airport site.

According to CENIPA (2015) statistics, the largest numbers of events occur in the approach phase for landing, followed in the takeoff and cruise phase. In the sense of ICAO (2013) "To the extent that safety risks are maintained under an appropriate level of control, a system as open and dynamic as aviation can still be managed to maintain an appropriate balance between production and protection".

Then, for Ashford (2015) "The combination of the probability of an event and its possible consequences defines the risk associated with the event." RBAC 164 (2014) in Paragraph (a) of the General Provisions of defines that "The danger caused by the presence of birds and other species of animals in the air operations makes it necessary for the public aerodrome operators, in order to carry out specific actions to manage the risk of collision between aircraft and the fauna, through an understanding of the factors risk and the definition of measures to eliminate or mitigate the risk."

The same RBAC 164 lays down in paragraph 1, supported by Law Nr. 12,725 October 16, 2012, Article 1 and paragraph $\vee$ which "Airport Security Area (ASA) means the circular area of the territory of one or more municipalities, defined from the geometric center of the largest aerodrome lane, with $20 \mathrm{~km}$ (twenty kilometers) radius, whose use and occupation are subject to special restrictions in attractive nature of fauna. Risks are still acceptable, but can lead to safety degradation propensities and catastrophic results."

For ICAO (2013) "Safety is a dynamic feature of the aeronautical system, where safety risks must be continually mitigated." Risk mitigation is defined as "The process of incorporating defensive and preventive controls to lower the severity and/or probability of a hazard of estimated consequence".

Allan (2006) apud CENIPA (2015) agree "There is no acceptable level of fauna risk or evaluation methodology established worldwide, conditions that is associated with the criterion of reducing this risk to the lowest possible level, contribute to simplifying the measurement of the same." The risk rate can be modeled by Poisson 
INDEPENDENT JOURNAL OF MANAGEMENT \& PRODUCTION (IJM\&P)

http://www.ijmp.jor.br

v. 10, n. 4, Special Edition IFLOG 2018

ISSN: 2236-269X

DOI: 10.14807/ijmp.v10i4.956

distribution. Accord with Fonseca and Martins (1994) the exponential distribution of Poisson is the decreasing function in time of density and is given by:

$\left\{\begin{array}{l}f(t)=0 \text { to } t<0 \\ f(t)=\lambda * e^{-\lambda * t} \text { to } t \geq 0, \lambda>0\end{array}\right.$

Or, by the function distribution and increasing in time to $t<0 ; f(t)=0$ and $t \geq 0 ; f(t)=\int_{0}^{t} \lambda * e^{-\lambda * t} d t=1-e^{-\lambda * t}$, where $\lambda$ is the observed or expected rate or frequency of collisions on one $t$ period considered. Given the function of partitioning, $t$ determines the probabilities of collisions, $P$, for a time, $t$, given by:

$P\left(T \geq t_{o}\right)=1-f\left(t_{0}\right)=1-\left[1-e^{-\lambda * t_{0}}\right]=e^{-\lambda * t_{0}}$

By the mean $(\mu)$ or variance of the collisions $\left(\sigma^{2}\right)$ for each particular specimen can be determined by $(\lambda)$ por: $\mu_{(t)}=1 / \lambda$; or $\sigma^{2}{ }_{(t)}=1 / \lambda^{2}$. The notation $X \approx \operatorname{Exp}(x)$ as an indicative that $X$ has exponential distribution according to the parameter $\alpha$ for the numbers of collisions registered in Brazil. The probabilities are inferred by integrating the corresponding graphical exponential functions, such that

$P(a \leq X \leq b)=\int_{a}^{b} \alpha * e^{-\alpha x} d x=-\left.e^{-\alpha x}\right|_{a} ^{b}=e^{-\alpha a}-e^{-\alpha b}$

Or,

$P(a \leq X \leq b)=\int_{a}^{b} \alpha * e^{\alpha x} d x=\left.e^{\alpha x}\right|_{a} ^{b}=e^{\alpha b}-e^{\alpha a}$

Accord with Magalhães and Lima (2013), based on the exponential model and where the variable $X$ represents the reference year, for $\alpha>0$. Then the density is $f(x)=\left\{\begin{array}{c}\alpha * e^{-\alpha x}, x \geq 0 ; \\ 0, \text { otherwise. }\end{array}\right\}$, or
$f(x)=\left\{\begin{array}{c}\alpha * e^{\alpha x}, x \geq 0 ; \\ 0, \text { otherwise. }\end{array}\right\}$

The uniform distribution of probability is given by the integral of the time interval of the function. For Magalhães and Lima (2013) to formalize the events of fauna impacts and their relationships with the sample data, the probability distribution function of the event is determined given by. The discrete random variable for a real number is defined. 
INDEPENDENT JOURNAL OF MANAGEMENT \& PRODUCTION (IJM\&P)

http://www.ijmp.jor.br

v. 10, n. 4, Special Edition IFLOG 2018

ISSN: 2236-269X

DOI: 10.14807/ijmp.v10i4.956

For Anderson, Sweeney and Williams (2011) the likelihood continuous time interval or time considered in the probability of collision events is represented. By the trends equations, the number of annual collisions is defined (Figure 8) and, therefore, it is inferred on the probability distributions of avian impacts for the coming years. Most of the specimens under study are not identified. The yearly probability of bird striking is agreement to $P=Y * 10^{-4}$ and as a function of data presented in Figure 8.

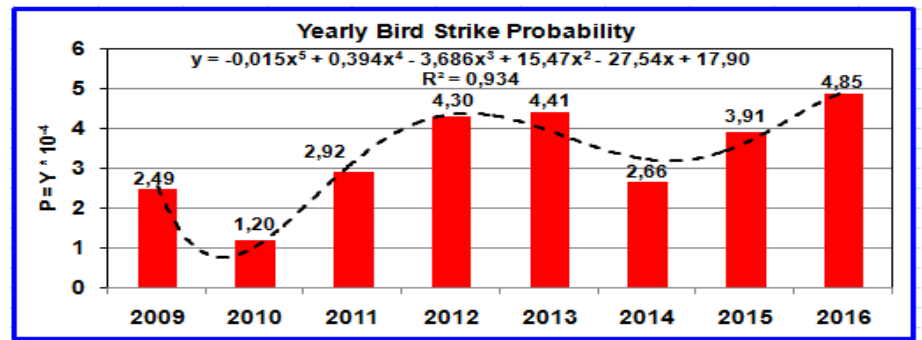

Figure 8 - Frequency of collisions (SBGR).

Source: The Author. (2018).

The frequencies of impacts were divided into twelve ranges of values with increments of 2.67; mean hourly impacts and sample standard deviation Figure 8 . The frequency of the bird impacts is according to the hourly function described in 6th order of the characteristic polynomial curve. The frequency density curves of the sample classes and the negative asymmetric histogram of the frequency densities Figure 9.

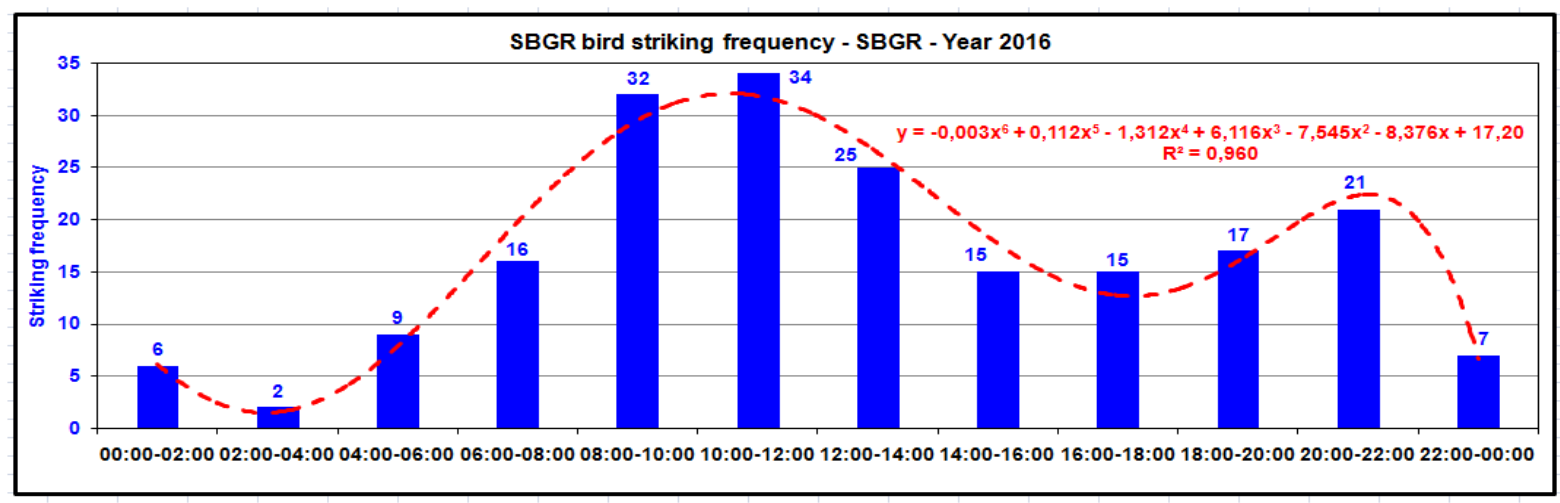

Figure 9 - Frequency of collisions (SBGR).

Source: The Author. (2018).

\section{CONCLUSIONS}

During the surveys there were no reports of fatalities in Brazil, other than scattered and not regularly reported reports on aircraft damage. The costs of structural repairs, systems, in addition to flight delays, fuel consumption resulting from collisions exceed $\mathrm{R} \$ 2$ billion per year. As mitigating measures, for example, the newest and most advanced system of navigation and satellite approach (GBAS), replacing the 
INDEPENDENT JOURNAL OF MANAGEMENT \& PRODUCTION (IJM\&P)

http://www.ijmp.jor.br

v. 10, n. 4, Special Edition IFLOG 2018

ISSN: 2236-269X

DOI: 10.14807/ijmp.v10i4.956

Instrument Landing System (ILS) with positioning accuracy within a radius of 1 meter and up to 60 meters, reduces flight time, in addition to the annual saving of $2.7 \%$ in the cost of aviation kerosene.

The system allows the direct landing, eliminates the traditional procedures in the traffic circuit in APPIATZ. This new procedure reduces the time in the air traffic circuit in low altitudes, where the chances of occurrences are much greater and, therefore, the less exposure to the avian risk.

The full effectiveness of the Law by preventing the practice of illegal landfills, irregular landfills, public awareness of the correct disposal of household waste, solid waste management, the use of falconry to inhibit avifauna in the airport perimeter, development of new non-aggressive techniques, the reduction of the neighborhood impact by the population density, are already significant contributors.

Silva (2015) agrees with the direct and indirect management of fauna employing the capture and translocation of birds, the use of trained dogs and falconry. The effectiveness of urban environmental planning and management, airport infrastructure and technological resources are necessary as mitigating actions.

These actions include restrictions on landfills, reduction of accumulated litter, lawn mowing, removal of shelter points in civilian structures and availability of water, noise repellents, use of radars on the airport site, etc. Considering that responsibility for the Environmental Impact Study (EIA) and for mitigation actions are also of airport management, however, it is up to all involved first and foremost.

Commissions should be formed by different professionals specialized in the specific areas in a joint way so that all the propositions with the lowest environmental impact and not have an academic context, but with objective evidence. Due to the instinct for procreation, food and water needs, many birds search the habitats of the forests in the vicinity of the Guarulhos airport site, which makes them susceptible to impacts with aircraft in the approach radius of the Sao Paulo TMA.

The striking report, sighting, or near collision should be reported by airlines to be given with less uncertainty about events. Effectives policies and actions with constant assessments of the performance of mitigating actions. Reforestation with native and fruit trees in areas remote from the airport radius will create attractiveness to the birds, moving them away and confining them naturally to those areas. 
INDEPENDENT JOURNAL OF MANAGEMENT \& PRODUCTION (IJM\&P)

http://www.ijmp.jor.br

v. 10, n. 4, Special Edition IFLOG 2018

ISSN: 2236-269X

DOI: 10.14807/ijmp.v10i4.956

The inaccuracies due to the associated uncertainties are significant because of the impossibility of identifying the many specimens involved and the omission of reports in events of avian impacts. Although events in those intervals are independents of each other's.

Probabilistic and predictability models imply margins of associated uncertainties due to numerable influencing factors such as climate change, land use and occupation, population density, food availability, and other related neighborhood impacts. Over ecosystem perspective, avian risk management should be such that it minimizes the impacts of neighborhoods on the biome, especially on wildlife, even though the focus is on air safety.

Although there are material losses and rare catastrophic damages, the greatest losses are those of the avifauna. Therefore, financial costs and materials with investments in non-aggressive devices, training and valuation of the professionals dedicated to airport security and air safety activities can be minimized. The proposals of mitigating solutions such as the extermination of the fauna which are said to represent a threat to the air movements are contradictory to the environmental policies.

Then it is imperative to conduct research to avoid them from the surroundings of the airport in order to reduce the frequency and severity of the strikes, without impacting on their natural habitats, through non-aggressive devices and without extermination of the species.

The sky of once winged were already dominated by the birds and it is up to all stakeholders to maintain this unspeakable right. It is the responsibility of all to minimize the impact on the inspirers who still graciously and perfectly challenge human eyes. The analysis of social, economic, material and environmental risks will be the theme of the next study. Exposed the analyses, discussions and results, concludes about the aviary impacts in the International Airport of Guarulhos.

\section{REFERENCES}

ACRP 125 (2015) Airport Cooperative Research Program. Balancing Airport Stormwater and Bird Hazard Management. Washington, D.C./U.S.A. Transportation Research Board. p. 3-6. Available: https://hazdoc.colorado.edu/bitstream/10590/5201/020347.pdf?sequence=1. Access: 08/21/2017. ISBN-10: 0309308305. ISBN-13: 978-0309308304 
ANDERSON, D. R.; SWEENEY, D. J.; WILLIAMS, T. A. (2011) Estatística Aplicada à Administração e Economia. $2^{\mathrm{a}}$ Ed. Translation.: José Carlos dos Santos. ERJ Composição Editorial e Artes Gráficas Ltda. São Paulo, SP. Cengage Learning.

ASHFORD, J. N.; MOORE, C. A.; STANTON, H. P. M.; COUTU, P.; BEASLEY, J. R. Airport Operations. 3rd Ed., U.S.A. McGrawHill Co., 2013. p. 128.

ASHFORD, J. N. et al. (2015) Operações Aeroportuárias: As melhores práticas. Tradução de Christiane de Brito Andrei e Patrícia Helena Freitas. $3^{\mathrm{a}}$ Ed. Porto Alegre, RS. Editora Bookman.

BRASIL. (1988) Constituição da República Federativa do Brasil. Promulgada em 05 de out. de 1988. $8^{\mathrm{a}}$ Ed. São Paulo, SP: Editora Atlas S.A., 1996.

BRASIL (2012) Lei № 12.725, De 16 de outubro de 2012. Presidência da Rep. Casa Civil. Subchefia para Assuntos Jurídicos. Brasília, DF, 2012. Available: http://www.planalto.gov.br/ccivil_03/_ato2011-2014/2012/lei//12725.htm. Access: 09/15/2017.

CARVALHO, J. C. M. (1995) Atlas da Fauna Brasileira. $3^{a}$ Edição. São Paulo, SP. Companhia Melhoramentos, 1995.

CENIPA (2016) Centro de Investigação e Prevenção de Acidentes Aeronáuticos. Estatísticas: panorama/fauna. Comando da Aeronáutica. Força Aérea Brasileira. 2016. Available: http://www2.fab.mil.br/cenipa/index.php/estatisticas/Panorama. pp. 35. Access: 08/21/2017.

CENIPA (2015) Centro de Investigação e Prevenção de Acidentes Aeronáuticos. CENIPA e empresas aéreas discutem risco de fauna em workshop em SP. Segurança de Voo. Pub.: 10 abr. 2015 - 14h30. Available in: goo.gl/LwNTgL. Access: 08/21/2017.

CGNA (2016) Centro de Gerenciamento da Navegação Aérea. Anuário Estatístico de Tráfego Aéreo 2016. Ministério da Defesa. Comando da Aeronáutica.

Departamento de Controle do Espaço Aéreo - DECEA. Rio de Janeiro, RJ, 2016. Available:

http://portal.cgna.gov.br/files/uploads/anuario_estatistico/anuario_estatistico_2016.pd f. Access: 08/22/2017.

FERREIRA, C. C.; CAMPOS, D. C.; OLIVEIRA, E. S. (2011) Guarulhos 450 anos: Atlas escolar histórico e geográfico. São Paulo, SP: Noronha América, 2011. Available: http://www.guarulhos.sp.gov.br/sites/ default/ files/atlas-escolar-histrico-geogrfico- subsite.pdf. Access: 08/28/2017. FONSECA, J. S.; MARTINS, G. A. (1994) Curso de Estatística. $5^{a}$ Ed. São Paulo SP. Atlas, 1994.

GRIMALDI, A. (2011) SPH High Velocity Impact Analysis: A Bird strike Windshield Application. Department of Aerospace Engineering. Univ. of Naples Federico II. Napoles, Italia, 2011. pp. 1. Available:

http://www.fedoa.unina.it/8221/1/grimaldi_arcangelo_23.pdf. Access: 08/28/2017. DOI: 10.6092/UNINA/FEDOA/8221.

ICAO (2013) International Civil Aviation Organization. Safety Management Manual (SMM). 3rd Edition. Doc 9859 - NA/474. Montreal, CA, 2013. pp. XII, pp. 2-1. Available: https://www.icao.int/safety/SafetyManagement/Documents/Doc.9859.3rd 
DOI: 10.14807/ijmp.v10i4.956

\%20Edition.alltext.en.pdf. Access: 08/24/2017. ISBN 978-92-9249-214-4.

ICAO (2017) International Civil Aviation Organization. 2008 - 2015 Wildlife Strike Analyses (IBIS). Electronic Bulletin 2017/25. Ed. 12 may. 2017. Available:

https://www.icao.int/safety/IBIS/2008\%20-

\%202015\%20Wildlife\%20Strike\%20Analyses\%20(IBIS)\%20-\%20EN.pdf. Access: 09/17/2017.

ICMBIO (2014) Instituto Chico Mendes de Conservação da Biodiversidade.

Relatório Anual de Rotas e Áreas de Concentração de Aves Migratórias no

Brasil. Diretoria de Pesquisa, Avaliação e Monitoramento da Biodiversidade. Coord. Geral de Manejo para Conservação. Brasília, DF, 2014. Available:

http://www.icmbio.gov.br/portal/images/stories/comunicacao/publicacoes/MioloRelatorio-Rotas-Migratorias_10-02-2015_Corrigido.pdf. Access: 08/28/2017.

ICMBIO (2014) Instituto Chico Mendes de Conservação da Biodiversidade. ICMBio atualiza mapa das rotas de aves migratórias no Brasil. Meio Ambiente, 2014. pp. 11. Available: http://ineam.com.br/icmbio-atualiza-mapa-das-rotas-de-avesmigratorias-no- brasil/. Access: 09/07/2017.

ICMBIO (2016) Instituto Chico Mendes de Conservação da Biodiversidade.

Relatório Anual de Rotas e Áreas de Concentração de Aves Migratórias no Brasil 2016. Brasília, DF. p. 18. Available:

http://www.icmbio.gov.br/portal/images/stories/DCOM_Miolo_Rotas_Migrat\%C3\%B3r ias_2016_final.pdf. Access: 08/28/2017.

MAGALHÃES, M. N.; LIMA, A. C. P. (2013) Noções de Probabilidade e Estatística. $7^{a}$ Edição. Reimp. rev. São Paulo, SP. Editora da Universidade de São Paulo, 2013.

NEUBAUER, K.; FLEET, D.; AYRES, M., Jr. (2015) ACRP 131 - A Guidebook for Safety Risk Management for Airports. National Academy of Sciences.

WASHINGTON, D.C.,U.S.A.: TRANSPORTATION RESEARCH BOARD, 2015. p. 20. Available: vsgc.odu.edu/ACRPDesignCompetition/2015/Resources for Design Competion Website/acrp_rpt_131_Safety Risk Management for Airports.pdfopen_in_new. Access: 09/06/2017. ISSN 1935-9802. ISBN 978-0-30930865-6. Library of Congress Control Number 2015938387.

OLIVEIRA, H. R. B.; SANTOS, L. C. B.; OLIVEIRA, C. M.; SILVA, J. P. (2016) Anuário de Risco de Fauna - 2015. Ass. de Ger. de Risco de Fauna, Brasília, DF: CENIPA. p. 15-27. Available:

http://www2.fab.mil.br/cenipa/index.php/estatisticas/risco-da-fauna. Access: $08 / 22 / 2017$.

QUINALHA, M. M.; CARVALHO, R. S. O.; RAMOS, S. G.; CHECON, C. T.; UBAID, F. K.; UIEDA, V. S.; NISHIDA, S. M. (2011) Que Bichos Moram no Jardim

Botânico do IB?. Projeto de Extensão Univ. Botucatu, SP. UNESP-PROEX, 2011. Available:

www2.ibb.unesp.br/Museu_Escola/Ensino_Fundamental/Animais_JD_Botanico/aves /documentos/anexos/GUIA_de Aves_JB (out-2011).pdf. Access: 09/06/2017.

RBAC No 164 (2014) Regulamento Brasileiro da Aviação Civil - Emenda № 00. Gerenciamento do Risco da Fauna nos Aeródromos Públicos. Brasília, DF - Brazil. Agência Nacional de Aviação Civil (ANAC), 2014. p. 1-4. Available: 
DOI: 10.14807/ijmp.v10i4.956

www.anac.gov.br/assuntos/legislacao/legislacao-1/rbha-e-rbac/rbac/rbac-164-emd00/@@display-file/arquivo_norma/RBAC164EMD00.pdfopen_in_new. Access: 09/07/2017.

SÁNCHEZ, L. E. (2011) Avaliação de impacto ambiental: conceitos e métodos. $3^{\mathrm{a}}$ Edição. São Paulo, SP: Oficina de Textos, p. 318-321.

SILVA, M. R. (2015) Biz. Aves e máquinas: quando muitos resolvem voar. Associação O Eco. Blog. Pub. 20 out. 2015 - 18h30.

Available:http://www.oeco.org.br/colunas/colunistas-convidados/aves-e-maquinasquando-muitos-resolvem-voar/. Access: 09/07/2017.

SOUTO, N. (2015) Aves Limícolas Migratórias Visitam o Brasil no Verão.

Publicado: 05 fev. 2015, 14h31. ICMBio - Instituto Chico Mendes de Biodiversidade. Brasília, DF: Ministério do Meio Ambiente. Available:

http://www.icmbio.gov.br/portal/ultimas-noticias/20-geral/6703-aves-limicolasmigratorias-visitam-o-brasil-no-verao. Access: 09/07/2017.

VAIRA, B. J. (2012) Estimating Bird/Aircraft Collision Probabilities and Risk Utilizing Spatial Poisson Process. USAF AFIT/IOA/ENS/12-06. Graduate Research Paper. Department of the Air Force. Air University Air Force Institute of Technology. Wright-Patterson Air Force Base. Ohio, U.S.A.. Available: http://www.dtic.mil/dtic/tr/fulltext/u2/a563995.pdf. Access: 08/28/2017. 